$\mid \begin{array}{cc}\mathbf{C}|\mathbf{O}| \mathbf{P}|\mathbf{E}| & \text { Turyzm/Tourism } \\ \substack{\text { Member since } 2019 \\ \text { JM14487 }} & 2021,31 / 1\end{array}$

\title{
HAS COVID-19 BROUGHT A TEMPORARY HALT TO OVERTOURISM?
}

\author{
Pinaz Tiwaria (iD, Nimit Chowdharyb (iD \\ ${ }^{a}$ Department of Tourism and Hospitality Management, Jamia Millia Islamia, New Delhi (India); \\ http://orcid.org/0000-0003-0631-3377; e-mail: tiwaipinaz@yahoo.com \\ ${ }^{\mathrm{b}}$ Department of Tourism and Hospitality Management, Jamia Millia Islamia, New Delhi (India); \\ https://orcid.org/0000-0002-7335-2379; e-mail: nchowdhary@jmi.ac.in
}

\begin{abstract}
COVID-19 has caused radical changes in the lives of people as well as economies. These changes are deemed as evolutionary and would bring a new phase of transformation. However, current practices of both people and businesses might cease once the crisis disappears. In the tourism context, going back to unsustainable and irresponsible practices would lead to the re-emergence of tourism aversion. This research note addresses the possibility that COVID-19 has only brought a temporary halt to the pre-existing issue of over-tourism and its related unsustainable practices. Even though the travel restrictions imposed by several countries amidst the spread of coronavirus have created a situation of "zero tourism", the tourism sector has now resumed its operations in most of the world. By presenting a conceptual framework, this note stresses that if the sector continues to act in the same way as before the virus, the situation of overtourism will re-emerge in the post-COVID-19 phase. Therefore, to prevent this issue, emphasising quality tourism, inculcating responsible behaviour, and the incorporation of technology are suggested.
\end{abstract}

\section{KEYWORDS}

COVID-19, overtourism, zero tourism, responsible behaviour, sustainable tourism

\section{ARTICLE INFORMATION DETAILS}

Received:

29 October 2020

Accepted:

11 May 2021

Published:

25 June 2021

\section{INTRODUCTION}

COVID-19 brought a sudden halt to social and economic activities globally from the beginning of 2020. Being one of the most vital socio-economic sectors, tourism has faced the repercussions of the imposition of restricted movement of people and transport. This restriction led abruptly to a situation of zero-tourism which led to the closure of businesses, unemployment and bankruptcy in the sector (World Travel and Tourism Council, 2020). As the world is fighting the pandemic and its adverse impacts, discourses on the "new normal" have amplified across different countries. Recent studies have addressed the pandemic as a transformative force in the field of tourism and hospitality (Brouder, 2020) and it is stated that the pandemic could be both a destroyer and a teacher which could create new habits despite the catastrophe (Tomes, 2010). However, immobility, the sudden halt of tourism activities, and the prevalence of social distancing measures have manifested themselves in a dilemma seen in the desire to "go back to normal" while rejecting the probable "new normal" (Brouder et al., 2020). Having said that, going back to normal would probably imply going back to unsustainable practices. The tourism industry is much criticised for focusing only on the "number of tourists" or "quantitative growth" rather than "qualitative growth" (Benner, 2020; Koens, Postma, 2018) which subsequently led to the existence at famous destinations of overtourism, tourismphobia, anti-tourism movements etc (Zerva, Palou, Blasco, Donaire, 2019). Indeed, a critical obstacle in the sustainable growth of tourism is the short-term vision 
of economic benefits that blurs a long-term desire for sustainable development. The 'agglomeration of adversities' caused by tourism is reflected through these issues. Despite the complexities that the concept of overtourism possesses, it is clear that the issue is widely prevalent in some popular tourist destinations (Bertocchi, Camatti, Giove, van der Borg, 2020; Hughes, 2018). However, after the outbreak of COVID-19, the issue has at least temporarily disappeared.

This research note emphasises that the pandemic has caused only a temporary halt to the pre-existing situation of overtourism and overcrowding. This work is future-oriented and centres on tourism's volatile nature while probing the re-emergence of overtourism after a vaccine is discovered and made available globally. The COVID-19 crisis apparently pressed the "reset button" on Earth. Nature felt alive, waters were clean (take the example of Venice), and the environment as a whole was cleaner than before (Muhammad, Long, Salman, 2020). Unquestionably, the pandemic is a blessing in disguise that has persuaded the world to rethink its actions.

\section{OVERTOURISM}

\section{- A RECAP OF THE PRE-COVID-19 PHASE}

Over the past decade, the exuberant growth in tourism attracted an increasing number of investors to the sector (World Tourism Organization, 2004). The year 2018 witnessed the movement of approximately 1.4 billion international tourists globally, and the target set for 2020 was swiftly achieved in 2018 itself. This unprecedented growth in the sector delivered not only economic benefits but also negative effects on communities (Murzyn-Kupisz, Holuj, 2020; Perkumienè, Pranskūnienè, 2019), the environment (Benner, 2019; Weber et al., 2017) and on destinations themselves. Several famous destinations like Venice, Barcelona, Maya Bay in Thailand, Dubrovnik, Amsterdam, and Machu Pichu had been significantly affected by the unprecedented growth in tourism and tourists. In 2018, overtourism became one of the controversial topics discussed in media as well as among academics (Goodwin, 2017; Muler Gonzalez, Coromina, Galí, 2018; Peeters et al., 2018), and subsequently became the "word of the year". The issue of contention is that "too" many tourists converge in the same destinations during the same period (Kuščer, Mihalič, 2019; Perkumienė, Pranskūnienè, 2019). The major causes that lead to this are an increase in disposable income, a desire to explore the world, rising options in accommodation and better connectivity than before supported the proliferation of tourism (Tiwari, Kainthola, Chowdhary, 2020a). Nevertheless, overtourism is not new (Wall, 2020) as the negative consequences of tourism were discussed implicitly if not explicitly in the 1960s. Like Doxey (1975) and Butler (1980), several authors have discussed the complications that host communities and destinations might face due to excessive tourism. Recently, Butler (2019) revisited the concept of capacity constraints as a leading cause of overtourism. In 1975, Pizam's study indicated that substantial tourism at a destination results in dissatisfaction among the host community and is reflected in their unhealthy attitudes (Pizam, 1978). This phenomenon is also manifested in the definition given by Harold Goodwin who defined overtourism as "destinations where hosts or guests, locals or visitors, feel that there are too many visitors and that the quality of life in the area or the quality of the experience has deteriorated unacceptably" (Goodwin, 2017, p. 1). In simple terms, overtourism occurs when the number of tourists is much greater than the capacity of a destination to withstand. Regarded as the antithesis of responsible tourism (Goodwin, 2017), overtourism is a fuzzy concept (Bertocchi, Camatti, Giove, van der Borg, 2020) as it involves specific perceptions related to tourists (Milano, Novelli, Cheer, 2019) and residents (Kuščer, Mihalič, 2019). Thereby, it is possible to realise that some of the occurrences are affecting popular destinations globally (Benner, 2020).

\section{HAS COVID-19 BROUGHT A TEMPORARY HALT TO OVERTOURISM?}

Harold Goodwin cautioned that overtourism could be expected in several destinations if tourism continues to grow unmanaged at the current pace (Goodwin, 2017). However, the world is so volatile that in 2020 the issue of overtourism has temporarily vanished. Due to the outburst of COVID-19, there has been a transition from overtourism to zero tourism. The researchers' most apparent prediction is a change in both tourists and locals' outlook. However, as the borders are set to reopen and restrictions on travelling are easing, the tourism sector is set to take steps to meet tourists' demands. Accordingly, this work conceptualises that overtourism might re-emerge in a post-COVID-19 phase as depicted in Figure 1. The 'return of overtourism' begins with the discovery and availability of a vaccine, followed by crisis of forgetfulness which would reduce the perceived risk and travel constraints. This phenomenon will influence tourism organisations and destination to adopt extensive growth strategy to recover the losses incurred due to the COVID-19. Ultimately, an increase in demand would lead to unsustainable and irresponsible practices disguised within a growth of the number of arrivals at destinations. Together this would cause overtourism to re-occur in the post-COVID-19 phase. 


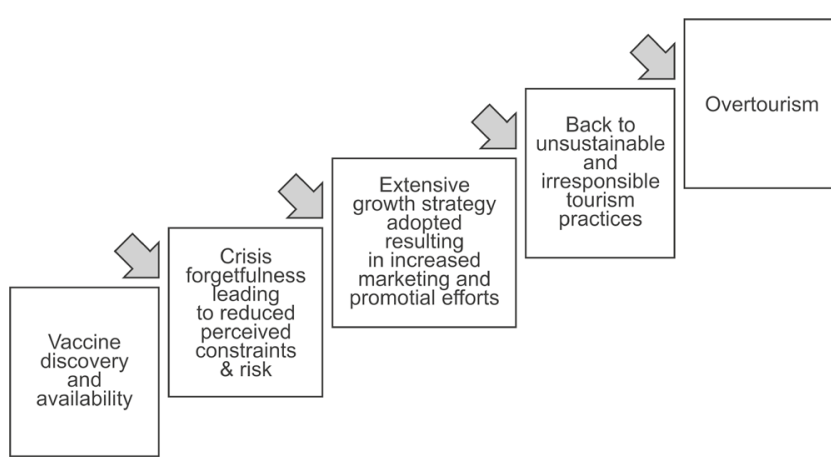

Figure 1. Conceptual framework for the re-emergence of overtourism

Source: authors

In the context of tourism crises, Farmaki (2020) has discussed tourists' post-crisis behaviour that reflects forgetfulness as evidenced by their travel resumption patterns. The author emphasised that tourists tend to forget about the crisis and resume travelling after being affected indirectly and after a large interval. This prospect is reinforced by changes in travel desires and motivations like visiting family and friends (Zenker, Kock, 2020) or the emergence of a 'tourist bubble' in the current situation (Lapointe, 2020). Extensive growth would be adopted by tourism organisations, to revitalise the sector and meet emerging demand, though less than usual. After COVID-19, the growth strategies are proactively developed by all tourism organisations i.e. both destination management organisations (DMOs) and tourism businesses to attract more tourists and revive the sector. Seraphin \& Ivanov (2020) introduced an extensive growth strategy that focuses on increasing the number of arrivals which requires an increase in marketing efforts by destination. To recover the losses incurred amidst the global health crisis, the tourism sector would increase its marketing and advertising to get back into the market, after the perceived risk decreases. Several tourism organisations have started issuing vouchers for future travel, and price deals would be found in the short-term. The national carrier of Germany, Lufthansa, anticipates that hundreds of their aircraft would be grounded by 2022, and the possibility of demand exceeding supply in the recovering phase could take place (Fanthorpe, 2020). The recent case of 'revenge tourism' promoted by the Chinese government (Kuo, 2020) is a suitable example to support our conceptual model.

Indeed, the tourism sector is far from perfect as evidence of pollution, economic costs on the host community and deterioration are prevalent, however it also brings enjoyment and transformative experiences for tourists and economic benefits for society (Butler, 2020). Thereby, a balanced approach is a pre-requisite for sustainable tourism. This approach implies synchronised steps towards acknowledging tourists' rights to travel and residents' rights to a quality of life. Making tourism a luxury service post-COVID-19 would restrain tourists from taking advantage of it. Likewise, excessive discounts and marketing campaigns could cause excess demand. Hence, more tourists at specific destinations could bring back overtourism and hamper residents' quality of life.

\section{THE WAY FORWARD TO}

\section{A PERMANENT SOLUTION TO OVERTOURISM}

Any phenomenon can render both positive and negative effects if not monitored effectively and monitoring through policy implementation could assist in designing policies and strategies appropriate for a destination. Certainly, issues related both to overtourism and zero-tourism are undesirable and have related adverse impacts on local communities and the industry. Undoubtedly, uncontrolled tourist numbers do not imply sustainable growth of a destination (Seraphin, Ivanov, 2020) nor did the absence of tourists demonstrate sustainable development. It is imperative to ensure that the world does not go back to its toxic attitudes and takes into account the recurring warnings that tourism has received for its unsustainability. Likewise, 'de-growth' in tourism would impoverish millions of people dependent on the sector for their livelihood. This calls for a balanced approach to prevent the issues of both overtourism and undertourism. Seraphin \& Ivanov (2020) consider that focusing on intensive growth related to revenue management would yield profits and avoid both overtourism and undertourism. Similarly, several solutions offered by researchers and policymakers such as the incorporation of demarketing strategies into the marketing mix (Tiwari, Kainthola, Chowdhary, 2020a), technological solutions to manage overtourism (Hospers, 2019), and tourism education to make destinations smart and sustainable (Tiwari, Kainthola, Chowdhary, 2020b) etc. However, most of the strategies are related to travel limitations, price differentiation, and increasing prices for a product which raises the question of tourists' right to travel. Moreover, considering that those who spend more at a destination would behave responsibly is an underlying myth.

Thus, this research note suggests that the adoption of quality tourism, the incorporation of technology in the consumption process and coordination among different components of tourism at a destination, along with re-analysing emerging trends in markets, followed by a repositioning of existing marketing strategies and the adoption of innovative products, would mean making a sustainable 'mandate' helpful in combating the ill effects of tourism in the post-COVID-19 phase 


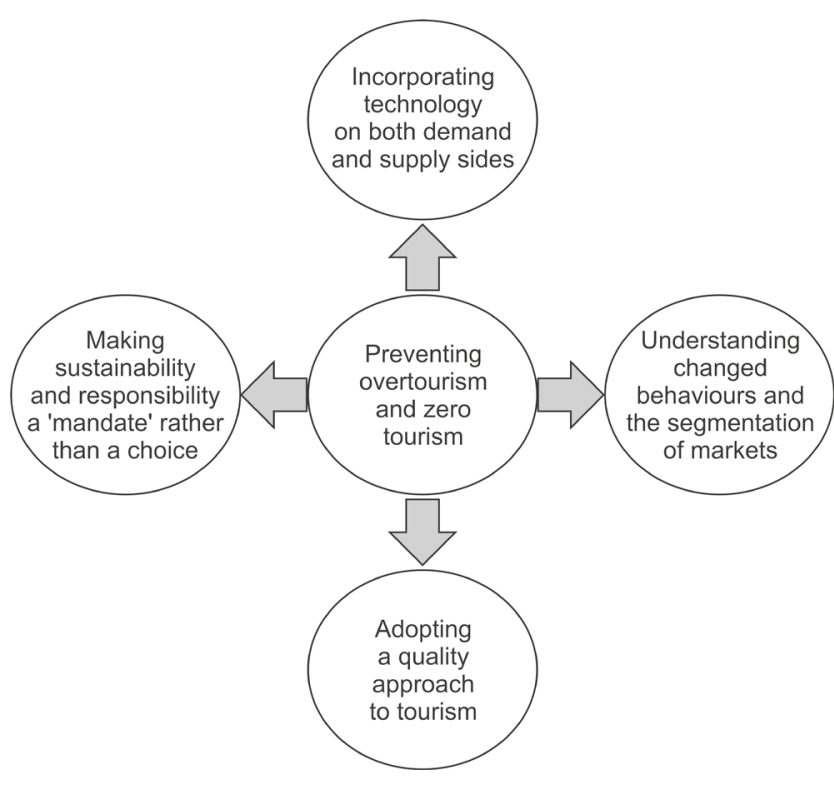

Figure 2. Preventing overtourism and zero tourism in the post-COVID-19 phase Source: authors

(Fig. 2). Covid-19 challenges mankind to ponder on the unsustainability of pre-COVID-19 travel. Nevertheless it is imperative that the tourism sector does not go back to practising the same negligent conduct that gave rise to its unsustainable practices.

\section{REFERENCES}

Benner, M. (2019). From overtourism to sustainability: A research agenda for qualitative tourism development in the Adriatic. Zeitschrift für Wirtschaftsgeographie = German Journal of Economic Geography, 2 (64), 74-87.

Benner, M. (2020). The decline of tourist destinations: An evolutionary perspective on overtourism. Sustainability, 12 (9), 3653. https://doi.org/10.3390/su12093653

Bertocchi, D., Camatti, N., Giove, S., van der Borg, J. (2020). Venice and overtourism: Simulating sustainable development scenarios through a tourism carrying capacity model. Sustainability, 12 (2), 512. https://doi.org/10.3390/su12020512

Brouder, P. (2020). Reset redux: Possible evolutionary pathways towards the transformation of tourism in a COVID-19 world. Tourism Geographies, 22 (3), 484-490. https://doi.org/10.1080/1 4616688.2020.1760928

Brouder, P., Teoh, S., Salazar, N.B., Mostafanezhad, M., Pung, J.M., Lapointe, D., Clausen, H.B. (2020). Reflections and discussions: Tourism matters in the new normal post COVID-19. Tourism Geographies, 22 (3), 1-12, 735-746. https://doi.org/10.1080/146 16688.2020 .1770325

Butler, R. (2020). From too many to too few: The impact of COVID-19 on overtourism. Retrieved from: https://blog.cabi.org/2020/06/02/ from-too-many-to-too-few-the-impact-of-covid-19-on-overtourism/ (12.09.2020).

Butler, R.W. (1980). The concept of a tourist area cycle of evolution: Implications for management of resources change on a remote island over half a century view project. Canadian Geographer, XXIV (1), 5-12. https://doi.org/10.1111/j.1541-0064.1980.tb00970.x
Butler, R.W. (2019). Tourism carrying capacity research: A perspective article. Tourism Review, 75 (1), 207-211. https://doi. org/10.1108/TR-05-2019-0194

Doxey, G.V. (1975). A causation theory of visitor-resident irritants: Methodology and research inferences. Sixth Annual TTRA Conference.

Fanthorpe, H. (2020). Could Covid-19 be the end of overtourism? Retrieved from: https://www.roughguides.com/article/could-covid-19-be-the-end-of-overtourism/ (13.09.2020).

Farmaki, A. (2020). Memory and forgetfulness in tourism crisis research. Tourism Management, 83, 104210. https://doi. org/10.1016/j.tourman.2020.104210

Goodwin, H. (2017). The challenge of overtourism. Responsible Tourism Partnership Working Paper, 4. Retrieved from: http:// haroldgoodwin.info/pubs/RTP'WP4Overtourism01'2017.pdf (12.07.2020).

Hospers, G.J. (2019). Overtourism in European cities: From challenges to coping strategies. CESifo Forum, 20 (3), 20-24.

Hughes, N. (2018). 'Tourists go home': Anti-tourism industry protest in Barcelona. Social Movement Studies, 17 (4), 471-477. https://doi.org/10.1080/14742837.2018.1468244

Koens, K., Postma, A. (2018). Understanding and managing visitor pressure in urban tourism. Retrieved from: https://www. celth.nl/sites/default/files/2018-09/Voorkomen\%20van\%20 bezoekersdruk\%20in\%20Europese\%20steden.pdf (17.03.2020).

Kuo, L. (2020). China promotes 'revenge travel' to boost economy after Covid lockdowns. Retrieved from: https://www.theguardian. com/world/2020/oct/01/china-promotes-revenge-travel-boost-economy-coronavirus-golden-week (2.10.2020).

Kuščer, K., Mihalič, T. (2019). Residents' attitudes towards overtourism from the perspective of tourism impacts and cooperation - the case of Ljubljana. Sustainability, 11 (6), 1823. https:// doi.org/10.3390/su11061823

Lapointe, D. (2020). Reconnecting tourism after COVID-19: The paradox of alterity in tourism areas. Tourism Geographies, 22 (3), 633-638. https://doi.org/10.1080/14616688.2020.17 62115

Milano, C., Novelli, M., Cheer, J.M. (2019). Overtourism and tourismphobia: A journey through four decades of tourism development, planning and local concerns. Tourism Planning and Development, 16 (4), 353-357. https://doi.org/10.1080/2156 8316.2019.1599604

Muhammad, S., Long, X., Salman, M. (2020). COVID-19 pandemic and environmental pollution: A blessing in disguise? Science of the Total Environment, 728, 138820. https://doi.org/10.1016/j. scitotenv.2020.138820

Muler Gonzalez, V., Coromina, L., Galí, N. (2018). Overtourism: Residents' perceptions of tourism impact as an indicator of resident social carrying capacity - case study of a Spanish heritage town. Tourism Review, 73 (3), 277-296. https://doi. org/10.1108/TR-08-2017-0138

Murzyn-Kupisz, M., Holuj, D. (2020). Museums and coping with overtourism. Sustainability (Switzerland), 12 (5). https:// doi.org/10.3390/su12052054

Peeters, P., Gössling, S., Klijs, J., Milano, C., Novelli, M., Dijkmans, C., Eijgelaar, E., Hartman, S., Heslinga, J., Isaac, R., Mitas, O., Moretti, S., Nawijn, J., Papp, B., Postma, A. (2018). Research for TRAN Committee - Overtourism: Impact and possible policy responses. European Parliament, Policy Department for Structural and Cohesion Policies, Brussels. Retrieved from: http://www.europarl.europa.eu/thinktank/en/document. html?reference=IPOL_STU(2018)629184 (8.07.2020).

Perkumienė, D., Pranskūnienė, R. (2019). Overtourism: Between the right to travel and residents' rights. Sustainability, 11 (7), 1-17. https://doi.org/10.3390/su11072138 
Pizam, A. (1978). Tourism's impacts: The social costs to the destination community as perceived by its residents. Journal of Travel Research, 16 (4), 8-12. https://doi.org/10.1177/004728757801600402

Seraphin, H., Ivanov, S. (2020). Overtourism: A revenue management perspective. Journal of Revenue and Pricing Management, 19 (3), 146-150. https://doi.org/10.1057/s41272-020-00241-7

Tiwari, P., Kainthola, S., Chowdhary, N.R. (2020a). Demarketing: A marketing framework for overtourism. In: C. Ribeiro de Almeida, A. Quintano, M. Simancas, R. Huete, Z. Breda (eds), Handbook of research on the impacts, challenges, and policy responses to overtourism (pp. 94-114). London: IGI Global. https://doi.org/10.4018/978-1-7998-2224-0.ch006

Tiwari, P., Kainthola, S., Chowdhary, N.R. (2020b). Empowering tourism education as a destination management tool. In: H. Seraphin, A. Yallop (eds), Overtourism and tourism education (pp. 63-80). London: Routledge.

Tomes, N. (2010). "Destroyer and teacher": Managing the masses during the 1918-1919 influenza pandemic. Public Health Reports, 125 (3), 48-62. https://doi.org/10.1177/00333549101250s308

Wall, G. (2020). From carrying capacity to overtourism: A perspective article. Tourism Review, 75 (1), 212-215. https://doi. org/10.1108/TR-08-2019-0356

Weber, F., Stettler, J., Priskin, J., Rosenberg-Taufer, B., Ponnapureddy, S., Fux, S., Camp, M.A., Barth, M., Klemmer, L.,
Gross, S. (2017). Tourism destinations under pressure. WorkingPaper. Lucerne University of Applied Sciences and Arts, Luzern. Retrieved from: https://static1.squarespace. com/static/56dacbc6d210b821510cf939/t/5909cb282e69cf 1c85253749/1493814076440/WTFL_study12017_full1version. pdf (12.07.2020).

World Tourism Organization (2004). Indicators of sustainable development for tourism destinations. In: Tourism's potential as a sustainable development strategy. Proceedings from the 2004 WTO tourism policy forum at the George Washington University, Washington, DC, USA: WTO.

World Travel and Tourism Council (2020). Leading global protocols for the new normal. (May). https://doi.org/10.1017/ CBO9781107415324.004. Retrieved from: https://wttc. org/COVID-19/Safe-Travels-Global-Protocols-Stamp (12.07.2020).

Zenker, S., Kock, F. (2020). The coronavirus pandemic - a critical discussion of a tourism research agenda. Tourism Management, 81, 104164. https://doi.org/10.1016/j.tourman.2020.104164

Zerva, K., Palou, S., Blasco, D., Donaire, J.A.B. (2019). Tourismphilia versus tourism-phobia: Rresidents and destination management organization's publicly expressed tourism perceptions in Barcelona. Tourism Geographies, 21 (2), 306-329. https://doi.org/10.1080/14616688.2018.1522510 